\title{
The Major Factors behind the Economic and Financial Crisis in Sudan
}

\author{
Adil Hassan Ibrahim ${ }^{1 *}$, Dyah Mutiarin M.SI ${ }^{2}$
}

${ }^{1}$ Master of Government affairs and administration, Postgraduate, College of Government studies, University of Muhammadiyah Yogyakarta, Indonesia ${ }^{2}$ Department of Government affairs and administration, School of Government, University of Muhammadiyah Yogyakarta, Indonesia

DOI: $10.36348 /$ sjef.2020.v04i12.007

| Received: 26.11.2020 | Accepted: 08.12.2020 | Published: 22.12 .2020

*Corresponding author: Adil Hassan Ibrahim

\section{Abstract}

Financial crisis is a phenomenon, which many researchers, writers, and organizations concern with it, therefore, this paper discusses the factors that cause a financial and economic crisis in Sudan. The purpose of this study is to investigate and understand the real factors that cause the economic and financial crisis in Sudan. This paper depends on the literature review and uses a descriptive approach to portray the main real causes of the economic and financial crisis in Sudan. To collect data and information, the investigator uses secondary data sources such as books, references, journals, the internet, newspapers, articles, reports, and other documents that are related to the topic. The findings of this paper represent four points namely; firstly, the initial reason number one that contributed to Sudan's financial crisis is the separation of South Sudan, secondly, the American economic sanctions against Sudan, thirdly the civil war and conflict in the west and new South Sudan. (South Kordofan), in addition to the corruption in its different shapes.

Keywords: financial crisis, American sanctions, separation, conflicts, inflation, corruption.

Copyright (C) 2020 The Author(s): This is an open-access article distributed under the terms of the Creative Commons Attribution 4.0 International License (CC BY-NC 4.0) which permits unrestricted use, distribution, and reproduction in any medium for non-commercial use provided the original author and source are credited.

\section{INTRODUCTION}

In 1929 there was a financial crisis in the USA and, many other countries in the world. It was followed by a large economic depression [1]. Between 20072009 there was another global financial crisis, it hit most of the countries in the world, the poor countries, and the rich countries [2]. Sudan was not an exception to this phenomenon. Sudan witnessed a very long civil war, between the central government in Khartoum and rebels in South Sudan, it was ended in 2005 by signing the Comprehensive peace agreement (CPA). In 2011 there was the separation of South Sudan which is considered as a very rich area with oil. In 2013 the central bank of Sudan declared that by the separation of South Sudan, Sudan has lost $75 \%$ of the oil revenues, the government thought about alternative policies for instance agriculture development, because more than $60 \%$ of the population of Sudan work in agriculture activities that provide $90 \%$ of the national food requests. In 2012 the inflation rate reached $44.4 \%$, in addition to the fiscal deficit and weakening of the exchange rate. The deficit of budget forced the government to borrow and call for assistance in several financial institutions to cover the deficit in her expenditures which represent goods and services. The expenditures are higher than revenues, that is why the government seeks to borrow from abroad, but at the same time borrowing leads to the raising of public debt, also government sometimes attempts to solve the problem of the deficit by printing banknote, but it led to the increasing of inflation. In 2020 the economic crisis in Sudan has worsened terribly, with the inflation rate jumping to more than $200 \%$, unemployment to about $66 \%$, and foreign debt to $\$ 64$ billion, according to independent reports [3]. The question that arises is: what are the major factors that cause a financial and economic crisis in Sudan?

\section{LITERATURE REVIEW \\ Concept of the Financial Crisis}

A financial crisis defines as a certain ultimate shock in a financial arrangement, that leads to disarrangement of the financial system's function, it involves debt crisis, banking crisis, stock market crash, and currency crisis. Also, a financial crisis can be defined as the following:

The financial crisis is the fall down of the financial system. The financial system includes all the bodies or agencies that do intermediation between borrowers and lenders, institutions of the stock exchange, and the focal bank acting as last resort lender [4]. Elryah \& Qian [5], discussed the separation of South Sudan in 2011, it is well-known that South Sudan is rich with petrol and it means that Sudan has lost a very rich part. In 2013 the central bank declared that with the secession of South Sudan, Sudan had missed 
$75 \%$ of the revenue of oil. Furthermore, they investigated the effect of inflation on the Sudanese economy, they said that; the inflation has increased in 2006 the inflation rate was $15.7 \%$ after the separation of South Sudan the prices index changed from $20.3 \%$ in 2011 to $36.5 \%$ in 2013.in 2014 the inflation rate reached over $44.4 \%$. in addition to that, the borrowing of government and raising taxes also contribute to the up come of inflation. In October 2019 the inflation rate was $57.7 \%$ according to Trading Economics [6].

Hamid E. Ali in 2012 discussed the impact of the Darfur conflict on the economics of Sudan; his calculations refer that the Sudanese government has incurred costs totaling US\$ 30.5 billion, equivalent to $171 \%$ of 2003 GDP on the armed conflict in Darfur, this involves $\$ 6.5$ billion in war impacts on the Gross domestic product, $\$ 4.1$ billion in the damage of infrastructure, $\$ 2.6$ billion has gone in foregone lifetime earnings of the dead, $\$ 7.2$ billion in the missed productivity of the IDP people and $\$ 10$. 1 billion direct expenditures of the military. He said that the combined costs of the war in Darfur are $\$ 41.5$ billion in case of adding spillover of military and AU/ UN crossbred in Darfur Peace-keeping process of $\$ 10.9$ billion. At the time, the government has spent only $1.3 \%$ of its budget on public health services, less than $1 \%$ on education services. The consumption of the war is $13 \%$ of the Gross domestic product in society that shortages the tools to save the basic service of the community representing in Education, health care, and infrastructures [7]. When there is talks about the financial crisis of Sudan, there should be talks about American Sanctions of Economic to Sudan. According to the U.S. view, Sudan considers as the state that sponsors terrorism and it became on the blacklist in 1993. The government of Sudan attempted many times to delete the name of Sudan, but no positive sign from the USA administration [8]. Since 1997 the USA has imposed economic sanctions against Sudan under IEEPA. President Clinton stopped the total of property and interests in property of the GOS that are within the USA or in the possession or the control of the United States of America, in addition to the imposition of trade sanctions [9]. the following are the most important prohibited dealings against Sudan, that reflect to finance, they are:

- Sudanese origins Goods and services are not allowed to import to the USA and vice versus.

- Direct or indirect exportation or re-exportation from the USA or any of USA Persons, of any services or goods or technology; involving software, technical data, or any other information to Sudan.

- The execution by any united states person of any convenes including public utility, commercial, financial contract, the projects of government, and in support of industrial in Sudan.

- Extension or grant of loans or credits by any United States person to the GOS.
- Any kind of transaction by a United States person linking to the transportation of cargo to or from Sudan [9].

In 2006 the sanctions of economic against Sudan increased by the U.S. in October 2017 the economic sanctions were lifted. This action created initial optimism, but commercial banks and foreign investors have been reluctant to relink. Financial transactions and trades between the world economy and Sudan remained very limited as the state of Sudan goes on to be designated by the United States of Americas as a country that looks after terrorism, protecting full normalization of connections with the U.S.A while there was an intention in late 2018 that discussing the remove of Sudan from the list of the States that sponsor the terrorism and talks expected to start soon [10]. In December 2018 peaceful protests started in Sudan and it toppled the regime of Omer albasher today prime minister Abdalla Hamdok attempts to discuss with the U.S.A. administration the matter of state that sponsors terrorism to remove the designation of Sudan from the blacklist.

\section{Types of a Financial Crisis}

There are many types of the financial crisis but most paramount are:

- Currency crisis: it takes place when there is a collapse of the fixed exchange rate regime [11]. One of the writers distinguishes between two types of currency crises namely: currency crash and currency debasement. Currency crash means annual depreciation versus the dollar of America or other international currencies such as the UK pound

- Banking crisis: it means the condition in which an actual or potential bank runs or fails to encourage the bank to suspend the inner convertibility of their liabilities [12].

- Foreign debt crisis: it occurs when the state is unable to services its external debt (repay).

- Balance of payment crisis: balance payment crisis is a structural imbalance between (capital and financial account) and deficit in the current account [12].

\section{Causes of the Financial Crisis of Sudan}

According to the literature review, the researcher deducted the causes of the financial crisis of Sudan as following:

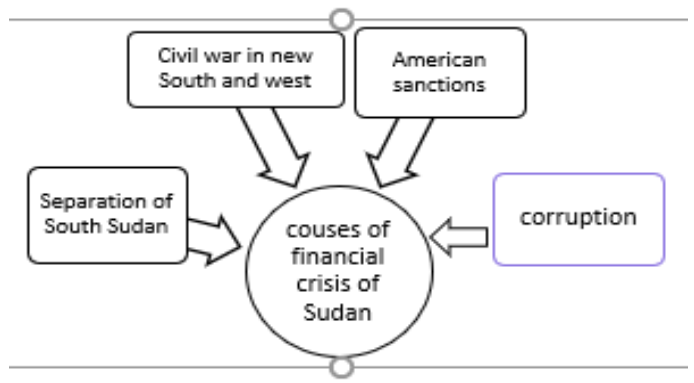

Source: A literature review. 


\section{Separation of South Sudan}

A comprehensive peace agreement (CPA) between the government of Sudan and South Sudan rebels of Sudan people's liberation movement (SPLM) was signed in 2005, the agreement involved the autonomy of the South Sudan government and it allows the South government to receive half of the oil revenue. Between 2005 and 2011 the two parties created a coalition, in 2010 the general elections took place, but it changed all the coalitions between NCP and SPLM because nearly all the political parties that expected to participate in the elections boycotted the general elections, therefore, the SPLM withdrew her representative in the presidency contestation and also the NCP withdrew its candidate in South Sudan, in the end, NCP won the elections. In 2011 there was a South Sudan self-determination referendum. The options were unity or separation. The outcome was for separation [13]. By the separation of South-Sudan, Sudan lost 75\% of petrol income, Sudan's budget became suffering from the high deficit. Financing the deficit budget and the pressure on the exchange rate led to escalating inflation, in 2011 the average of inflation was $15.3 \%$ and it was expected to be $25 \%$ in 2012 [5]. In October 2019 the inflation rate was recorded at $57.70 \%$ [14]. After the secession of South- Sudan, North Sudan's currency pound lost its value more than $60 \%$ on the informal market (black market) comparing with the foreign currency like the dollar. The government officials realized that the deterioration of the economy is the first factor that threatens the stability of the regime, in the same time the regime fights the rebel in more than three fronts, therefore it leads to the weakness of the ruling party and government [15].

The figure below illustrates the inflation rate in Sudan since 1984-2020.

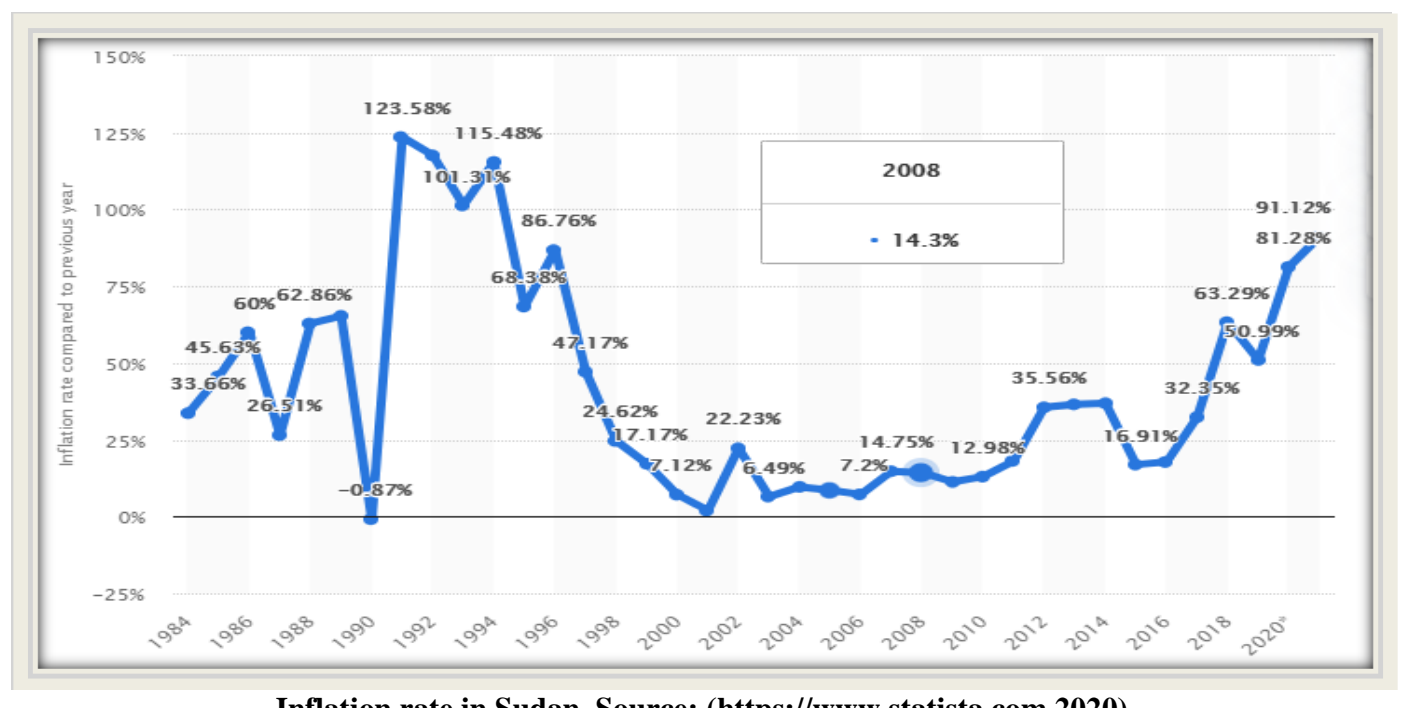

Inflation rate in Sudan. Source: (https://www.statista.com 2020)

\section{Civil war in new south and western Sudan:}

The war in Darfur between rebels and the government of Sudan, started on the $26^{\text {th }}$ of February 2003 when the rebels invaded the garrison of the military of government in a locality called Golo eastern Marra mountain. Hamid (2013) found that military spending affects negatively the growth of the economy. Expending to the military in Sudan has increased, and the defense outgo in Sudan is characterized by camouflage, according to Hamid's study, in 2004 the government spent more than $40 \%$ of GDP on the army, also he noted that other authors claim that it constitutes $70 \%$ of GDP. Before the war, the government was expending $\$ 845$ on the military, after the war started it doubled. The cumulative rise of expenditure between 2004 and 2009 was estimated at $\$ 10$ billion [16]. The total costs of Military expenditures from 2003 to 2017 reached to US\$88.7 billion [17]. According to (Sentry) an organization that observes the funding of conflicts in Africa says $70 \%$ of expenditures of the Sudan government go to the security sector and inflation has taken place as a result of war costs in Darfur, South Kordofan and the Blue Nile. The Sudan government warfare expending estimated to $\$ 4$ million per day. In his speech in the headquarter of Sudan Air forces, Basher the president at that time said " it is not enough even if the whole budget $(100 \%)$ of the country spent to Army to keep the security of the state" [18].

\section{American Sanctions}

In 1956 Sudan gained its independence from Britain and Egypt, in the same year diplomatic relations with the U.S.A started [19]. In 1967 Sudan's diplomatic relations with the U.S. broke because of the war between Arab and Israel. In 1971 the relations again improved, but in 1986 the relations got worse when U.S.A. bombed Tripoli- Libya, in April 1986 one of the U.S. employees was shot, following this accident all non-essential employees left the country. In 1990 the relations of the U.S with Sudan tensioned when Sudan support Iraq in her invasion of Kuwait and delivering assistance to terrorist groups, in the middle of the 1990s 
the famous terrorist groups were hosted in Sudan Such as Osama bin Laden and Abu Nidal. In 1993 U.S. classified Sudan as one of the states that sponsor terrorism. In October 1997 there was an imposition of comprehensive economic sanctions against Sudan by the U.S.A government [20] the American economic sanctions against Sudan had a negative impact on education, health, civil infrastructure, technology, finance of family, anti-government sentiment, local business, and social entrepreneurship initiatives [21].

Institutional Causes: (Absences of political integrity, financial mismanagement, and corruption widespread).

The institutional causes of the financial crisis in Sudan include a high rate of corruption, an absence of political integrity, and a lack of trust, which leads to the failure of the efforts of the government to burden the manifestations of corruption in Sudan. It is definitely clear, that Sudan could not improve its corruption perceptions index (CPI). According to the data gathered by the transparency international organization about the corruption perception index in 2019, Sudan is one of the countries that show indicators in their efforts of anti-corruption and that do not engage the most relevant social, political, and business actors in decision-making. Between $2018-2019$, Sudan is one of the top ten highly corrupted countries (their scores are very low), these countries include Somalia, South Sudan, Syria, Yemen, Afghanistan, and Sudan, respectively [22].

\section{METHODOLOGY}

This qualitative research uses a descriptive approach in order to gain a deep understanding and further perspectives on the factors that stand behind the financial and economic crisis in Sudan. To collect the data and information the researcher uses secondary data sources such as books, references, reports of the government of Sudan and international organizations, the internet, journals, newspapers, and other subjects that relevant to the topic. The articles and books have been collected from recognized websites such as Google scholar, IEEE explore, and Springer link. The researcher chose this method because it is suitable for describing such phenomena. The site of the study was Sudan, Sudan is one of the developing countries in Africa, it is situated in the north-east of the African continent, the total area of Sudan is $2,505,813$ square kilometers; 2,376,000 square kilometers of land; 835 kilometers of coast. Sudan's total area now stands at $1,861,484$ square kilometers. Geographically it was the biggest country in Africa until 2011.

\section{RESULTS AND DISCUSSIONS}

According to the secondary data, the researcher reached the following findings:

1. The most important factor that caused the financial crisis in Sudan is the secession of South Sudan, because when it took place, Sudan lost around $75 \%$ of the oil revenue, in the time, when there was no alternative plan for the exportations. Also, Sudan's currency lost its value more than $60 \%$ in the black market and inflation went very high. The terms of the Comprehensive Peace Agreement (CPA) of January 9, 2005, which aimed to end 22 years of civil war between the North and the South, enabled South Sudan's independence. The agreement calls for the 2010 South Secession National Elections and Referendum.

2. The second factor that caused the financial crisis in Sudan is the Civil war which took place in Western Sudan - the Darfur region, South Kordofan, and the Blue Nile. The war cost the government a lot of money, spending most of the state budget on defense and security ignoring the other services such as education, health, and so on. To emphasize, this, the previous president of Sudan Omer AL basher said if all the budget of the state spent to the security forces it would not be enough. At a time of worsening violence in the far-flung country of Darfur, the breakthrough in the North-South peace process has arrived. Two rebel groups launched attacks in Darfur in early 2003, namely the Sudan Liberation Movement (SLM) and the Justice and Equality Movement (JEM).

3. The third factor which contributes to the financial crisis of Sudan is American economic Sanctions against Sudan which imposed in 1997 as a result of that Sudan had hosted terrorist groups. Sudan declared war on Israel after the start of the SixDay War in June 1967 and broke diplomatic relations with the United States. After July 1971, when the Communist Party of Sudan attempted to overthrow President Nimeiry, relations changed, and Nimeiry suspected Soviet interference Following the 1972 peace settlement that ended the First Sudanese Civil War with the North, relations strengthened further after the U.S. provided assistance to resettle refugees. Also one of the factors that led to the economic and financial crisis in Sudan is corruption in its different images.

\section{CONCLUSION}

This paper has argued the causes and the factors that lead to the financial crisis in Sudan these causes are:

i. The separation of South Sudan which was a very rich area with petrol.

ii. The imposition of American economic sanctions against Sudan and also setting Sudan on the blacklist.

iii. The civil war in New South Sudan (South Kordofan) and western Sudan Darfur. In this case, the government ignored many fields and became interesting only in security and defense, meanwhile, the education and health sector was 
completely not supported. To collect data and information the researcher used secondary data sources that involve books, references, journals, and other documents that are related to the topic.

iv. Absence of integrity, transparency in government institutions. (corruption).

\section{REFERENCES}

1. Hall, R. E. (2010). Why Does the Economy Fall to Pieces after a Financial Crisis ? 24(4), 3-20.

2. Claessens, S., Kose, A., \& Fund, I. M. (2018). Introduction and Description of Financial. (February 2013). https://doi.org/10.2139/ssrn.2295201

3. Abdelrahman, K. (2020). Sudan... The economy's crisis is getting worse, and experts identify 5 causes and 7 solutions. In Sky News Arabia.

4. Global, I. (2019). https://www.igiglobal.com/dictionary/global-financial-crisis-andbank-productivity-in-mexico/11108.

5. Elryah, Y., \& Qian, N. Q. (2015). Injections into the Dutch Disease: Do IMF Packages and Foreign Aids Recover Sudan's Economy? Journal of International Economics, 6(1):118-131. Retrieved from http://www.ipeindia.org

6. Tradingeconomics. (2019). Sudan Inflation Rate Trading Economics.

7. Ali, H. E. (2012). Estimate of The Economic Cost of Armed Conflict: A Case Study From Darfur.

8. Approved, F., \& No, O. M. B. (2018). US Rapprochement with Sudan: State Sponsor of Terrorism No More Erwin James Wunderlich A paper submitted to the Faculty of the United States Naval War College Newport, RI in partial satisfaction of the requirements of the Department of National Security. (0704).

9. U.S. Department of the Treasury. (2016). Office of Foreign Assets Control (OFAC). 4. Retrieved from

https://www.treasury.gov/about/organizationalstructure/offices/Pages/Office-of-Foreign-AssetsControl.aspx

10. Sudan, the world bank in. (2019). https://www.worldbank.org/en/country/sudan/over view.

11. Riley, G. https://www.tutor2u.net/economics/reference/fina ncial-economics-types-of-financial-crisis.

12. Racickas, E., \& Asta, V. (2012). Classification of Financial Crises and their Occurence Frequency in Global Financial Markets. Social Research, 4(29), 32-44.

13. Weis, T. (2012). Sudan after Separation: New Approaches to a New Region (Vol. 28). Retrieved from http://www.boell.de/en/content/sudan-afterseparation-new-approaches-new-region

14. Https://tradingeconomics.com/sudan/inflationcpi?continent=australia. (2019). Sudan Inflation Rate.

15. Window), S. on T. (opens new, Window), S. on F. (opens new, Window), S. on L. (opens new, Save, \& Wallis, W. (2011). https://www.ft.com/content/ce7f675a-f8c9-11e0ad8f-00144feab49a.

16. Ali, H. E. (2013). Estimate of The Economic Cost of Armed Conflict: A Case Study From Darfur. Defence and Peace Economics, 24(6), 503-519. https://doi.org/10.1080/10242694.2012.723154

17. Ali, H. (2014). Darfur: The Estimated Impact of Military Spending.

18. Nuba Reports. (2016) https://qz.com/africa/615938/sudan-could-spendup-to-70-of-its-budget-on-several-war-fronts-thisyear/.

19. https://www.state.gov/u-s-relations-with-sudan/. (2019).

20. https://sd.usembassy.gov/our-relationship/policyhistory/us-sudan-relations/. (n.d.).

21. Malik, M., \& Malik, M. (2015). The Efficacy of United States Sanctions on the Republic of Sudan. Journal of Georgetown University-Qatar Middle Eastern Studies Student Association, 2015, 7. https://doi.org/10.5339/messa.2015.7

22. Mohamed, S. S. O. (2020). Overview of the Sudan Uprising - Before, During and After the Revolution. University Bremen, Germany. 